\title{
Rancang Bangun Mesin Uji Universal Untuk Pengujian Tarik dan Tekuk Bertenaga Hidrolik
}

\author{
Nanang Ali Sutisna ${ }^{1, a}$, Sigit Winardi ${ }^{2, b}$ and Agung Suhartono ${ }^{3, c}$ \\ 1,2,3 Program Studi Teknik Mesin, Universitas Presiden, \\ Jababeka Education Park, Cikarang Timur, Bekasi, Indonesia \\ ananang.ali@president.ac.id, bwinardi605@gmail.com, cagung.Suhartono@mane.com
}

\begin{abstract}
Abstrak.
Mesin Uji Universal atau UTM (Universal Testing Machine) adalah mesin pengujian material yang memiliki lebih banyak dari satu jenis pengujian material. Tujuan penelitian ini adalah perancangan dan analisis kekuatan konstruksi UTM untuk uji tarik dan uji tekuk. Mesin ini menggunakan dongkrak hidrolik sebagai sumber daya untuk memberikan beban yang diperlukan. Desain dibatasi pada beban 1,4 ton sedangkan beban konstruksi maksimum adalah 5 ton sesuai kapasitas dongkrak hidrolik. Metoda yang dilakukan dalam penelitian ini diawali dengan perancangan dengan menggunakan CAD dan kemudian dianalisis dengan metoda elemen hingga.

Dari hasil analisis dan evaluasi, alat yang dirancang dapat digunakan dengan aman sesuai dengan spesifikasi yang digunakan. Hasil penelitian menunjukkan bahwa dari hasil percobaan pada spesimen uji tarik dan uji tekuk, kedua pengujian berhasil dilakukan. Uji tarik dilakukan dengan material SUS 304 dan SS400 dengan ketebalan berbeda dengan dimensi sesuai standar ASTM E8, sedangkan uji tekuk dilakukan pada material ASTM A36 dengan ukuran 200 x 40 x 6 mm. Setelah pengujian dilakukan, konstruksi mesin diperiksa terhadap kemungkinan cacat akibat pengujian, yaitu clamp atas dan bawah, punch dan dies, serta rangka mesin. Sebagai kesimpulan, setelah dilakukan pengujian ternyata pada semua bagian yang diperiksa tidak ditemukan kerusakan atau cacat..
\end{abstract}

Kata kunci. Rancang bangun, Mesin Uji Universal, Uji Tarik, Uji Tekuk .

\begin{abstract}
.
Universal Testing Machine or UTM (Universal Testing Machine) is a material testing machine that has more than one type of material testing. The purpose of this research is to design and analyze the strength of the UTM construction for tensile and bending tests. This machine uses a hydraulic jack as a power source to provide the required load. The design is limited to a load of 1.4 tons while the maximum construction load is 5 tons according to the hydraulic jack capacity. The method used in this study begins with a design using CAD and then analyzed with the finite element method.

From the results of the analysis and evaluation, the designed tool can be used safely in accordance with the specifications used. The results showed that from the experimental results on the tensile and bending test specimens, both tests were successfully carried out. The tensile test was carried out with SUS 304 and SS400 with different thicknesses with dimensions according to ASTM E8 standards, while the bending test was carried out on ASTM A36 material with a size of $200 \times 40 \times 6 \mathrm{~mm}$. After the test is carried out, the construction of the machine is checked for possible defects due to the test, namely the upper and lower clamps, punches and dies, and the engine frame. As a conclusion, after testing, it turns out that no damage or defects were found in all the parts examined.
\end{abstract}

Keywords: Design and Fabrication, Universal Testing Machine, Tensile Test, Bending Test 


\section{Pendahuluan}

Pada industri rekayasa teknik, kebutuhan terhadap variasi material sangat penting untuk menunjang adanya inovasi dan perubahan pada produk-produk yang dihasilkan maupun pembuatan mesin-mesin baru. Material tersebut perlu diverifikasi sifat fisik dan non-fisiknya agar dapat dipertanggung jawabkan. Untuk mengetahui sifat fisik suatu material dilakukan melaui tahapan pengujian yang banyak, salah satu pengujiannya adalah uji mekanis. Pengujian mekanis adalah pengujian material yang dapat diklasifikasikan menjadi pengujian merusak (destructive test) dan pengujian tidak merusak (non-destructive test). Secara umum pengujian merusak digunakan untuk mengetahui sifat mekanis suatu material antara lain tensile, fatigue, bending dan lain-lain, sedangkan pengujian tidak merusak digunakan untuk mengetahui cacat suatu material tanpa merusak material yang diuji.

Salah satu alat yang digunakan untuk melakukan pengujian mekanis adalah Mesin Uji Universal (Universal Testing Machine atau UTM). UTM adalah suatu mesin uji mekanis terhadap material yang dapat digunakan untuk melakukan lebih dari satu metode pengujian. Jenis pengujian yang bisa dilakukan pada mesin ini adalah uji tarik [1], uji bending (Bending Test) [2,3], dan pengujian kekuatan geser.

Mesin uji universal sudah banyak diproduksi dengan bermacam-macam sistem kerja dan memiliki beragam kapasitas. Secara umum, Mesin uji universal menggunakan sistem kerja hidrolik dan motor listrik sebagai daya penggerak untuk melakukan pengujian. Sistem kerja dengan kekuatan hidrolik lebih mudah diaplikasikan [4], biaya sistem dan instalasi yang lebih murah, dan testing range lebih luas karena tenaga yang dihasilkan lebih besar. Sedangkan mesin dengan sistem kerja motor listrik diaplikasikan pada material tertentu yang tidak membutuhkan kekuatan uji yang besar. Berdasarkan latar belakang yang telah dipaparkan, disini penulis bermasud untuk membuat rancang bangun Mesin Uji Universal untuk pengujian tarik dan tekuk menggunakan sistem hidrolik dengan memanfaatkan dongkrak hidrolik (bottled jack).

\section{Metodologi}

Rancang bangun Mesin Uji Universal ini dilakukan dengan tahapan-tahapan sebagaimana diperlihatkan dalam diagram alir pada Gambar 1 di bawah ini.

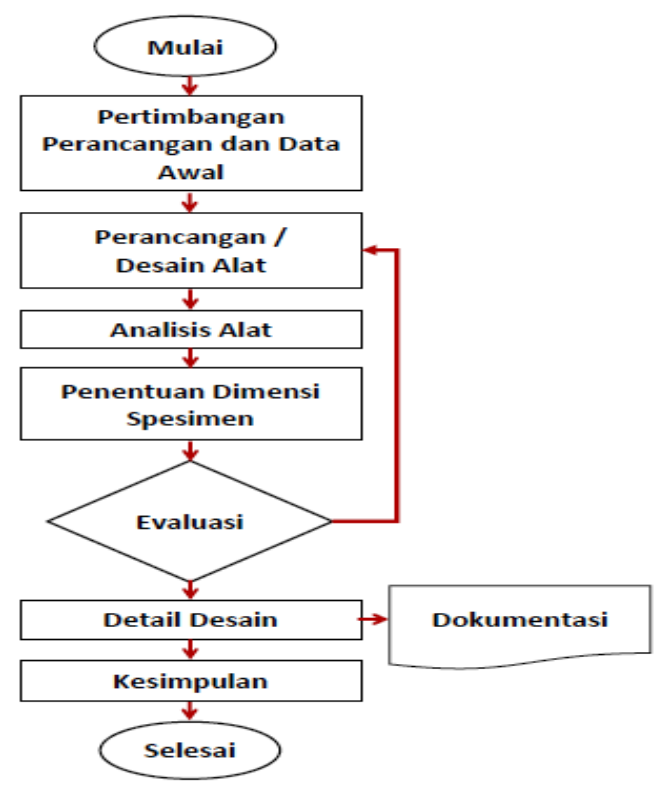

Gambar 1. Diagram alir rancang bangun Mesin Uji Universal 


\section{Pertimbangan Perancangan Alat}

Pertimbangan perancangan alat didasarkan dari konseptual rancangan yang diinginkan seperti rupa, fungsi dan inovasi yang dipakai. Mesin Uji Universal (UTM) ini terdiri atas mesin uji tarik dan mesin tekuk yang tertanam pada satu sistem dan penggerak mesin untuk penggerak punch dan clamps adalah dongkrak hidrolik yang memiliki kapasitas desain 5 ton. Pertimbangan rancangan secara rinci adalah sebagai berikut:

1. UTM terbuat dari 1023 Carbon Steel Sheet (SS) dengan referensi sifat mekanis material dari aplikasi Solidworks.

2. Mesin tekuk plat dirancang untuk melakukan uji tarik dan penekukan pada material jenis pelat menggunakan sebagian kapasitas kerja hidrolik dari dongkrak, yaitu sebesar $1400 \mathrm{~kg}$, mengingat ketersedian komponen hidrolik yang ada di pasaran.

3. Dimensi spesimen uji tarik berdasarkan kepada standar ASTM E8 [5]

4. Dimensi spesimen uji tekuk memiliki lebar $40 \mathrm{~mm}$ dan panjang $200 \mathrm{~mm}$, mengacu kepada standar ASTM E-290 [6], dengan material terbuat dari ASTM A36

5. Mekanisme penekukan menggunakan gaya dari sistem hidrolik (bottle jack).

6. Bentuk punch dan die yang digunakan dibuat sendiri.

7. Sistem clamping, punch dan dies dirancang dan dibuat sendiri.

Spesimen uji tarik yang dipakai adalah spesimen plat (rectangular cross-section specimen). Ketebalan spesimen disesuaikan ketentuan lebar plat dari standar dan nilai area uji tarik di atas, yaitu disesuaikan dengan standar ASTM E8 sebagaimana terlihat pada Gambar 2.

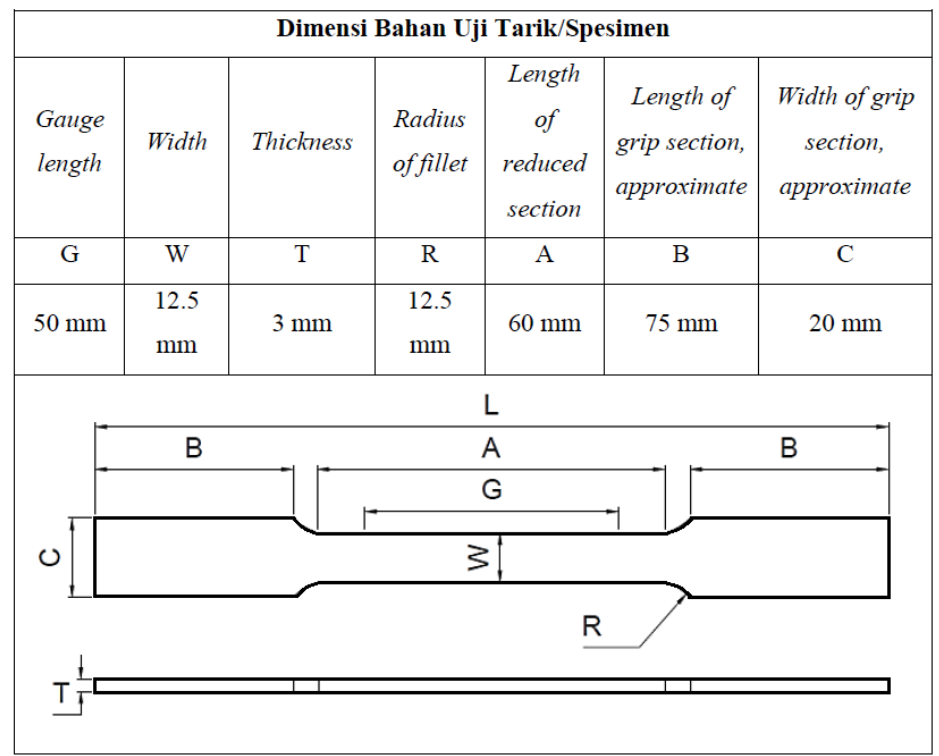

Gambar 2. Spesimen uji tarik sesuai standar ASTM E8

Sedangkan spesimen uji tekuk memiliki lebar $40 \mathrm{~mm}$ dan panjang $200 \mathrm{~mm}$. Adapaun ketebalan material uji/spesimen dicari berdasarkan kapasitas baben rancangan yaitu $1400 \mathrm{~kg}$, maka ketebalan pelat spesimen dapat dihitung sebagai berikut [7]:

$$
\mathrm{F}_{\text {maks }}=\mathrm{K} \frac{U T S x L x T^{2}}{W} \quad \text { atau } \quad \mathrm{T}=\sqrt{\frac{F_{\text {maks }} \times W}{K x U T S \times L}}
$$

dimana:

UTS : Ultimate tensile strength material ASTM A36 $=400 \mathrm{~N} / \mathrm{mm} 2$

L : Lebar benda kerja maksimum $=40 \mathrm{~mm}$

$\mathrm{T} \quad$ : Tebal benda kerja maksimum

Fmax : Gaya maksimum dari beban $1400 \mathrm{~kg}=14000 \mathrm{~N}$

$\mathrm{K} \quad$ : Konstanta $=1$

$\mathrm{W} \quad$ : Die opening $=50 \mathrm{~mm}$ 
Sehingga $\mathrm{T}=\sqrt{\frac{1400 \times 50}{1 \times 400 \times 40}}=6.5 \mathrm{~mm}$,

maka tebal pelat ditetapkan $6 \mathrm{~mm}$ sesuai yang tersedia di pasaran. Dimensi spesimen lengkapnya adalah panjang $200 \mathrm{~mm}$, lebar $40 \mathrm{~mm}$, dan teal $6 \mathrm{~mm}$.

\section{Perancangan Alat}

Rancangan Mesin Uji Universal ini dibuat dengan menggunakan Solidworks dengan komponenkomponen frame, dongkrak hidrolik, bagian uji tarik, dan bagian uji tekuk, seperti terlihat pada Gambar 3 di bawah ini. Ketinggian mesin UTM ini dirancang untuk melakukan pengujian secara berdiri sehingga memudahkan operator dalam mengoperasikan dongkrak.

Keterangan:

1. Frame

2. Dongkrak Hidrolik

3. Uji tarik (Tensile test)

4. Uji tekuk (Bending test)

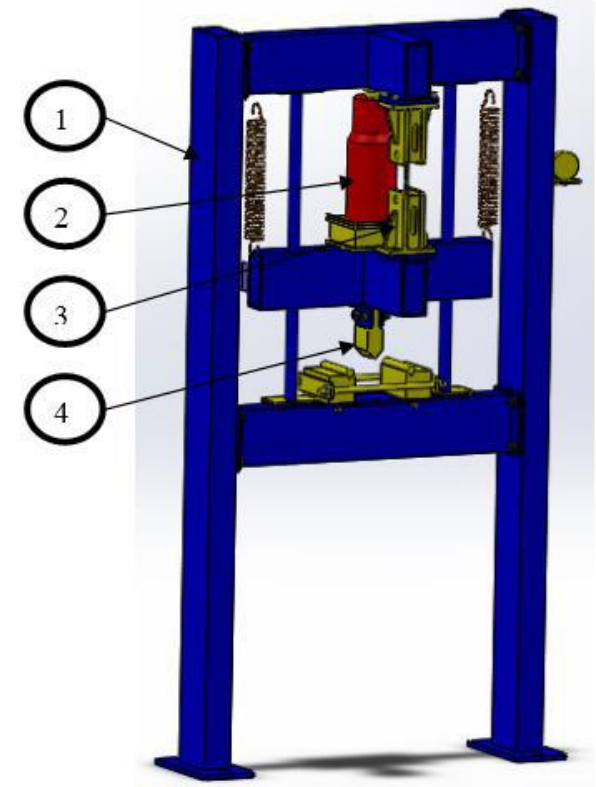

Gambar 3. Konstruksi mesin UTM

\section{Analisis Konstruksi Alat Menggunakan Simulasi Solidworks}

Analisa yang dilakukan adalah analisa ketahanan konstruksi alat terhadap gaya/beban yang terjadi saat mesin bekerja menggunakan fungsi simulasi di Solidworks. Tahap pertama adalah melakukan validasi ukuran elemen (mesh study) untuk menentukan ukuran elemen yang tepat agar hasil simulasi memiliki tingkat akurasi yang baik, hal ini terkait dengan seberapa kecil suatu elemen harus dibuat untuk memastikan agar hasil analisis tidak terpengaruh oleh perubahan ukuran mesh (mesh convergence) [8]. Gambar 4 menunjukan hasil studi pengaruh perubahan ukuran elemen mesh terhadap Von Mises yang terjadi. Perubahan ukuran elemen dari $8 \mathrm{~mm}$ ke $5 \mathrm{~mm}$ menghasilkan Von Mises yang tidak terlalu besar sehingga dianggap elemen dengan ukkuran $5 \mathrm{~mm}$ telah konvengen, untuk selanjutnya ukuran elemen $5 \mathrm{~mm}$ akan digunakan dalam analisis elemen hingga pada konstruksi mesin UTM ini.

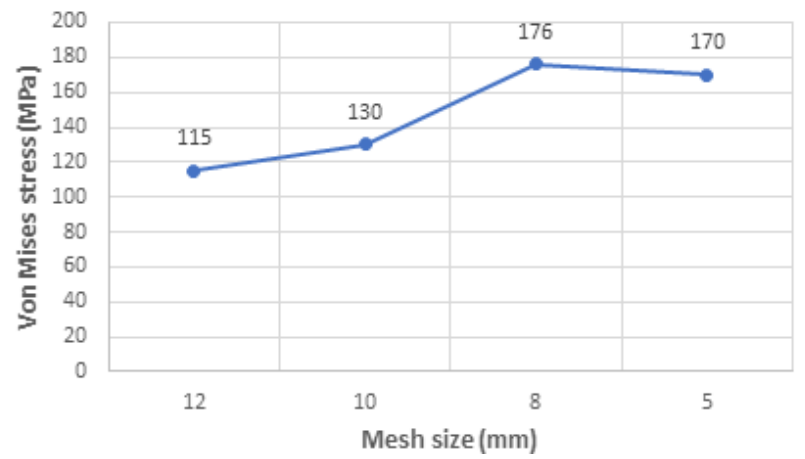

Gambar 4. Mesh study, ukuran mesh 5 mm sudah dapat mewakili konvergensi 
Selanjutnya dilakukan simulasi pada saat dilakukan uji tarik dengan beban tarik 1,4 kN yang menghasilkan tegangan Von Mises maksimum $114 \mathrm{MPa}$ (lihat Gambar 5). Jika dibandingkan dengan kekuatan luluh (yield strength) yaitu sebesar $282 \mathrm{MPa}$ maka konstruksi bagian uji tarik memiliki faktor keamanan 2,47 .

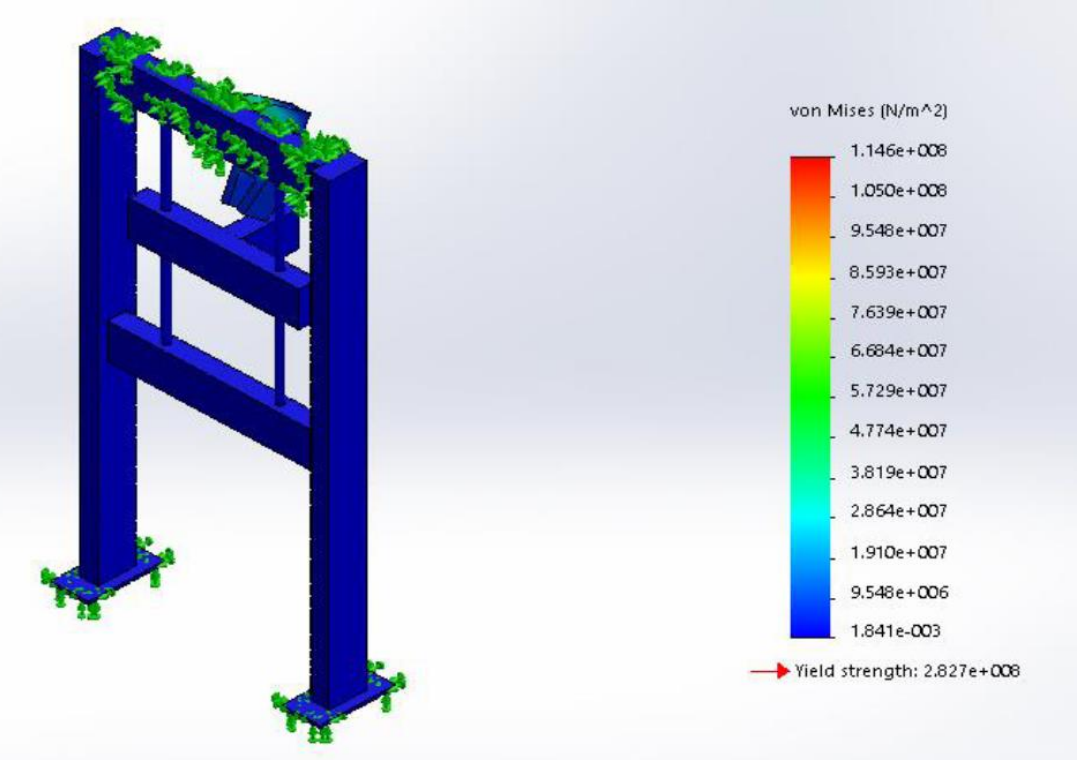

Gambar 5. Von Mises stress yang terjadi saat simulasi uji tarik

Kemudian dilakukan simulasi ketahanan konstruksi saat uji tekuk. Hasil simulasi saat uji tekuk dapat dilihat pada Gambar 6 di bawah ini. Gambar 6a memperlihatkan besaran tegangan Von Mises saat terjadi proses uji tekuk, sedangkan Gambar $6 \mathrm{~b}$ memperlihatkan besarnya perpindahan.

Simulasi saat terjadi uji tekuk dengan beban sebesar 1,4 kN menghasilkan tegangan lentur (bending stress) maksimum sebesar 0.9 Mpa sebagaimana terlihat pada Gambar 5. Sedangkan Gambar 6 memperlihatkan perpindahan (displacement) maksimum sebesar 0,15 mm. Kedua hal ini mengindikasikan bahwa konstruksi mesin UTM ini aman terhadap beban yang terjadi akibat percobaan tekuk.
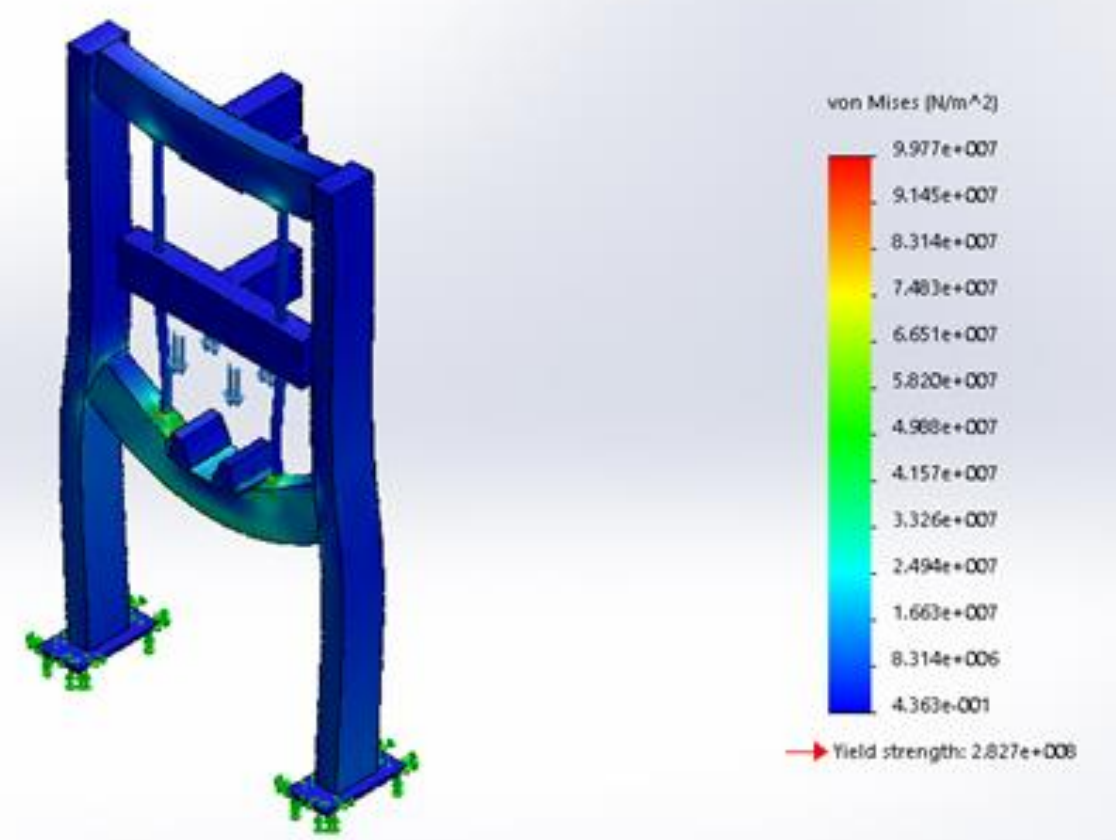

Gambar 6 a. Von Mises stress yang terjadi saat simulasi uji tekuk (bending) 


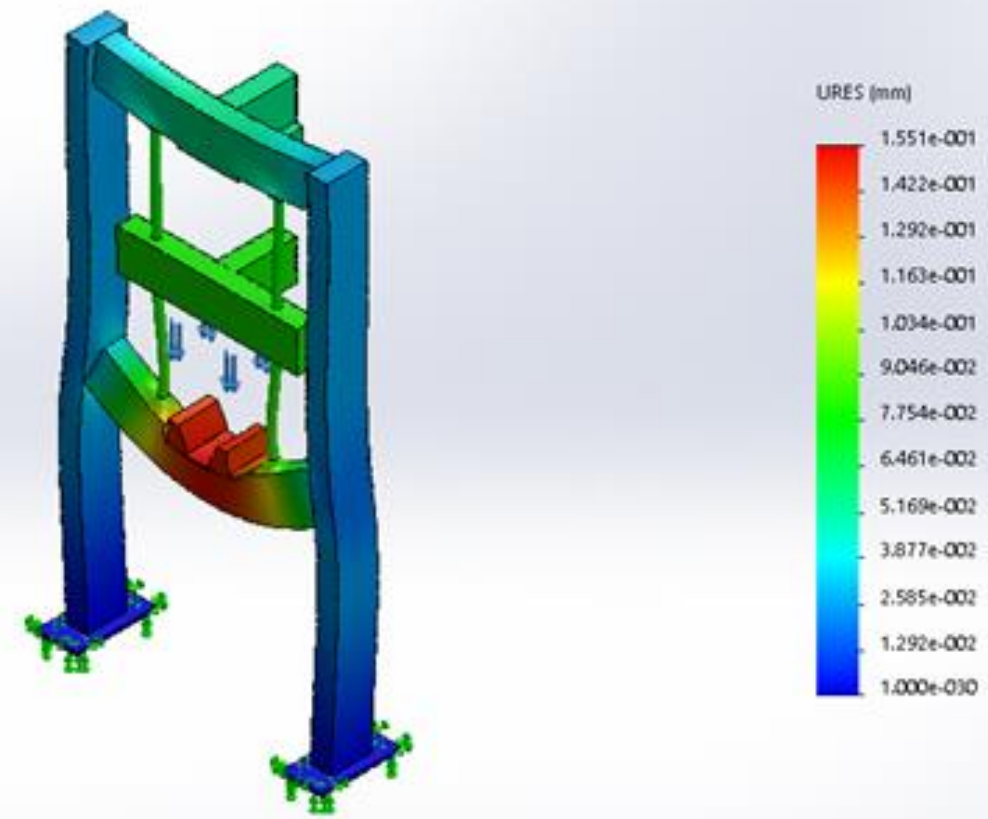

Gambar 6 b. Perpindahan (displacement) yang terjadi saat simulasi uji tekuk (bending)

\section{Pengujian Alat}

Setelah Mesin Uji Universal ini dibuat, maka selanjutnya dilakukan pengujian terhadap alat yang telah dibuat dengan melakukan uji tarik dan uji tekuk menggunakan spesimen standar sebagaimana telah diuraikan sebelumnya pada bagian Pertimbangan Perancangan.

Berikut dibawah ini terlihat pada Gambar 7a kondisi spesimen dengan ketebalan $3 \mathrm{~mm}$ sebelum percobaan uji tarik, sedangkan Gambar 7b memperlihatkan kondisi spesimen setelah dilakukan uji tarik.

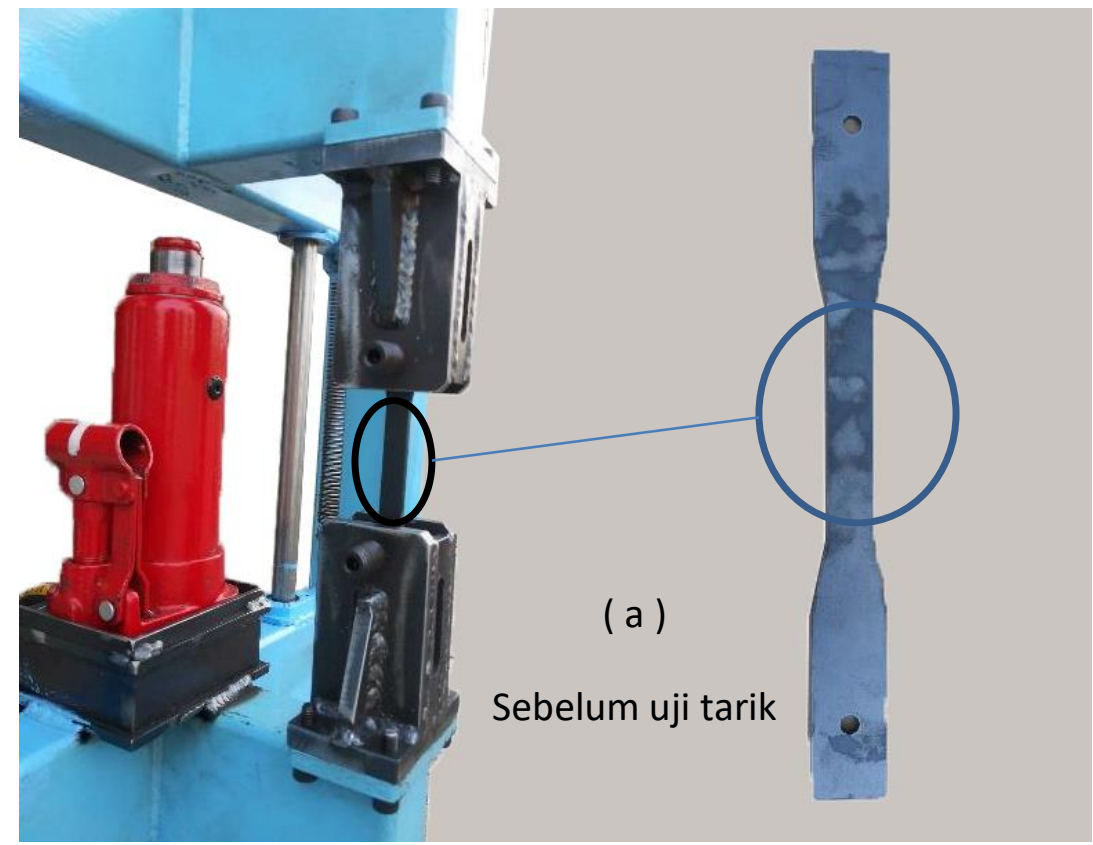




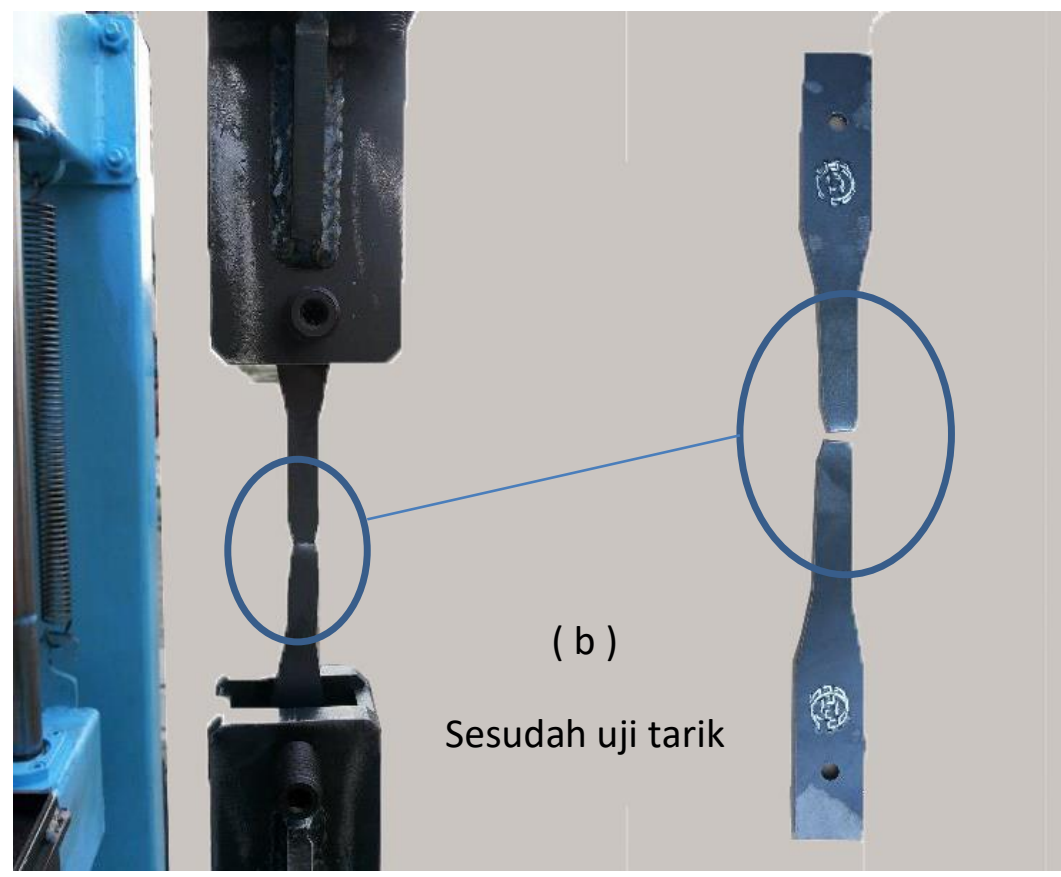

Gambar 7. Kondisi spesimen sebelum dan sesudah uji tarik

Percobaan uji tarik dilakukan pada spesimen dengan material dan ketebalan berbeda, hasil pengujian dapat dilihat pada Tabel 1 . Karena mesin ini dioperasikan secara manual maka tidak memungkinkan untuk memantau berapa besarnya gaya penarikan atau penekanan pada saat terjadi pertambahan panjang, sehingga tidak dapat digambarkan hubugan antara tegangan dan regangan.

Tabel 1. Hasil uji tarik pada spesimen denagn tebal dan material yang berbeda

\begin{tabular}{|l|c|c|c|c|c|}
\hline Material & \multicolumn{2}{|c|}{ SUS 304} & \multicolumn{3}{c|}{ SS 400} \\
\hline Ketebalan Spesimen, $\mathrm{t}(\mathrm{mm})$ & 1.5 & 2 & 1.6 & 3.2 & 2.3 \\
\hline Panjang Awal Spesimen, I0 (mm) & 200 & 200 & 200 & 200 & 200 \\
\hline Panjang Spesimen Setelah Uji Tarik, li (mm) & 248 & 235 & 225 & 220 & 220 \\
\hline Perubahan panjang, $\Delta \mathrm{I}(\mathrm{mm})$ & 48 & 35 & 25 & 20 & 20 \\
\hline Elongation $(\mathrm{mm})$ & $24 \%$ & $17.5 \%$ & $12.50 \%$ & $10 \%$ & $10 \%$ \\
\hline
\end{tabular}

Percobaan uji tarik tersebut menujukkan bahwa mesin UTM dapat menguji spesimen dengan material berbeda dan ketebalan yang berbeda. Mesin UTM dapat digunakan secara versatil untuk menguji berbagai jenis material. Akan tetapi karena penekanan dilakukan dengan dongkrak hidrolik yang dioperasikan secara manual dan belum dilengkapi dengan load cell untuk memantau besarnya gaya yang diberikan maka tidak dapat digambarkan hubungan antara tegangan dan regangan.

Adapun hasil bending pada pengujian material ASTM A36 dapat dilihat pada gambar 8 di bawah ini. Gambar 8 (1) memperlihatkan awal penekukan di saat alat penekan menyentuh pelat spesimen, kemudaian penekanan diteruskan hingga pelat uji mulai tertekuk seperti terlihat pada Gambar 8(2).

Selanjutnya penekukan dilanjutkan sampai pelat mendekati batas alas dan akhirnya berakhir setelah pelat uji menyentuh batas alas mesin penguji, seperti digambarkan pada Gambar 8 (3) dan (4),

Dari gambar di atas, dapat dilihat bahwa spesimen berhasil ditekuk menggunakan UTM. Dapat disimpulkan bahwa UTM bekerja dengan baik sesuai fungsi kerjanya untuk pengujian tarik maupun penekukan spesimen. Sama seperti halnya pada uji tarik, pada mesin UTM ini belum bisa mengukur gaya maksimum penekukan sehingga belum bisa memperlihatkan tegangan lentur secara langsung. 


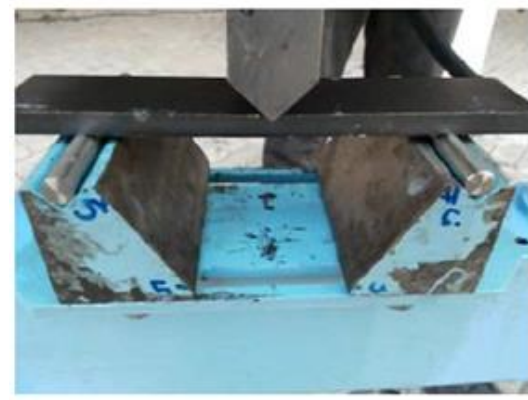

1.

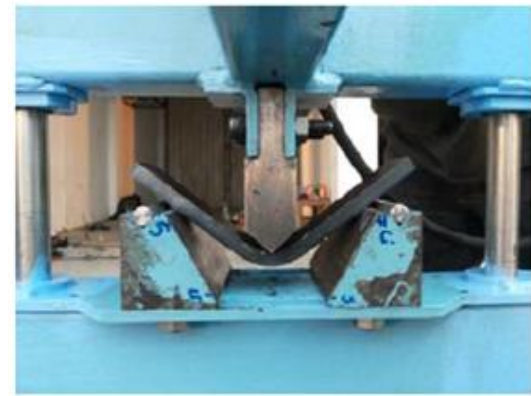

3
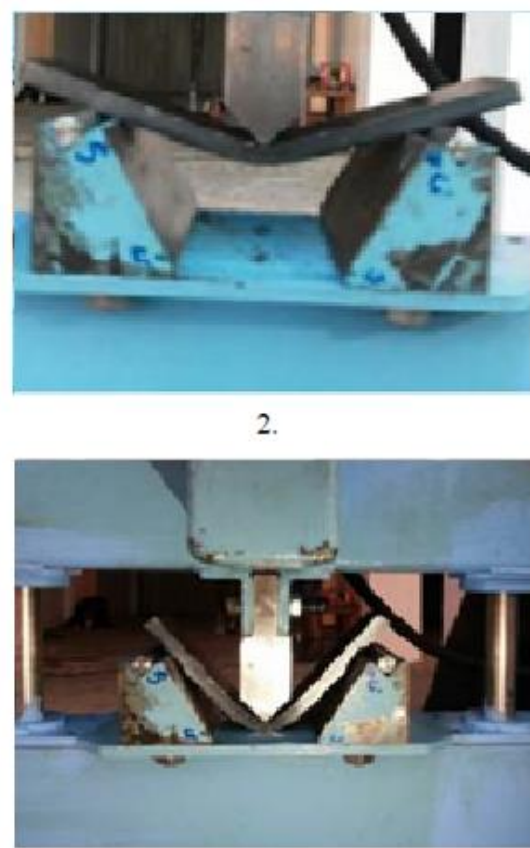

4

Gambar 8. dokumentasi uji bending dari mulai (1) hingga berakhir (4)

\section{Kondisi Penjepit Sesudah Uji Tarik}

Clamp terdiri atas sepasang, yaitu clamp atas (fixed) yang menahan spesimen dan clamp bawah (moving) yang bergerak menarik spesimen. Gambar 9 berikut ini menunjukkan kondisi clamp atas sebelum dan sesudah percobaan uji tarik. Dari gambar tersebut, dapat dilihat bahwa tidak ada kecacatan yang terjadi pada clamp, baik rangka clamp maupun baut clamp untuk clamp atas dan clamp bawah.
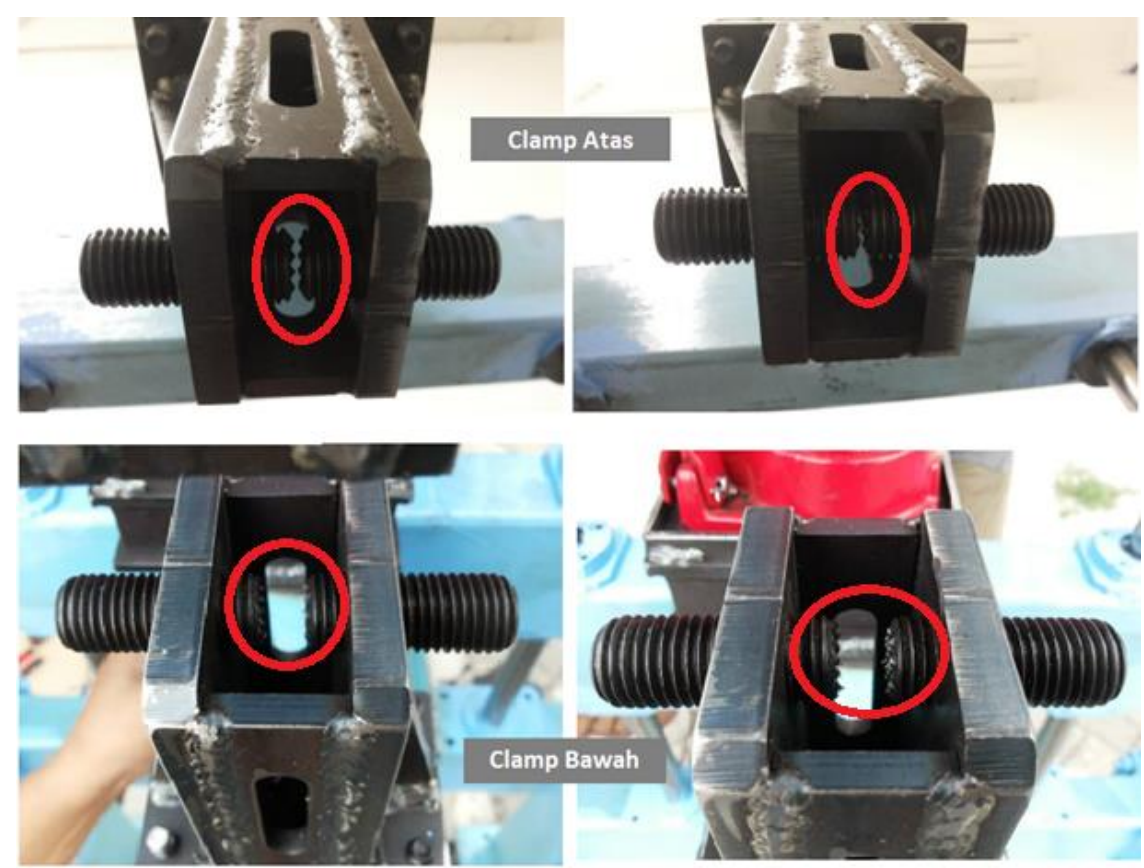

Sebelum uji tarik

Sesudah uii tarik

Gambar 9. Kondisi clamp atas dan bawah sebelum dan sesudah uji tarik

\section{Kondisi Punch dan Die Sesudah Uji Tekuk}

Berikut ini adalah pemeriksaan punch dan die setelah melakukan uji tekuk. Gambar 10 di bawah ini adalah kondisi punch dan die sebelum dan setelah melakukan penekukan benda kerja. Dari gambar 
10 tersebut, dapat dilihat bahwa tidak ada kerusakan/cacat yang terjadi pada punch dan die dengan membandingkan keadaan sebelum dan sesudah UTM melakukan uji tekuk. Maka dapat disimpulkan bahwa punch dan die kokoh dan aman melakukan fungsinya sesuai dengan beban kerja UTM

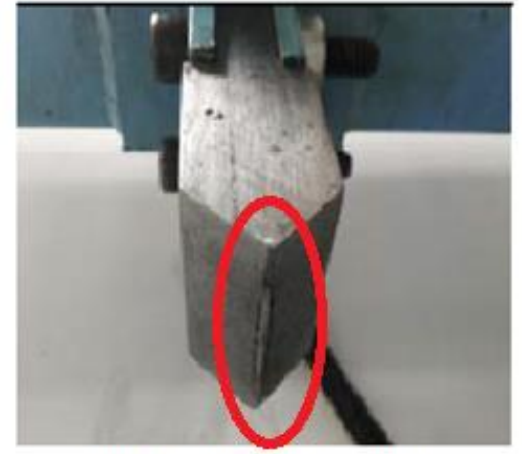

Punch sebelum uji tekuk

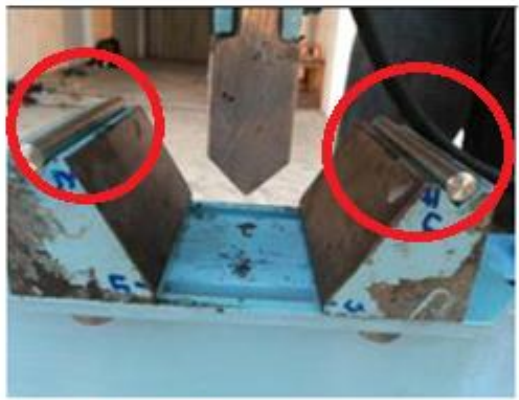

Die sebelum uji tekuk

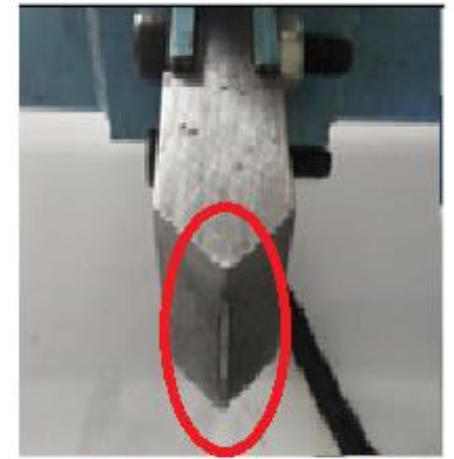

Punch sesudah uji tekuk

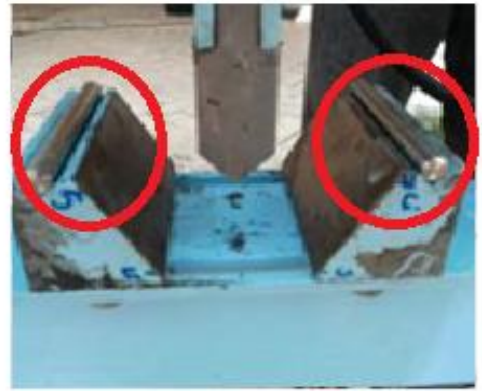

Die sesudah uji tekuk

Gambar 10. Kondisi punch dan die sebelum dan sesudah uji tarik

\section{Kondisi Rangka Sesudah Uji Tarik dan Tekuk}

Selanjutnya rangka diperiksa dari kemungkinan cacat setelah digunakan uji tarik dan uji tekuk. Dari gambar 11 di bawah, dapat dilihat bahwa tidak ada kecacatan yang terjadi pada keseluruhan rangka UTM, terbukti Waterpass yang terletak diatas rangka alat menunjukkan bahwa alat tidak mengalami kemiringan.

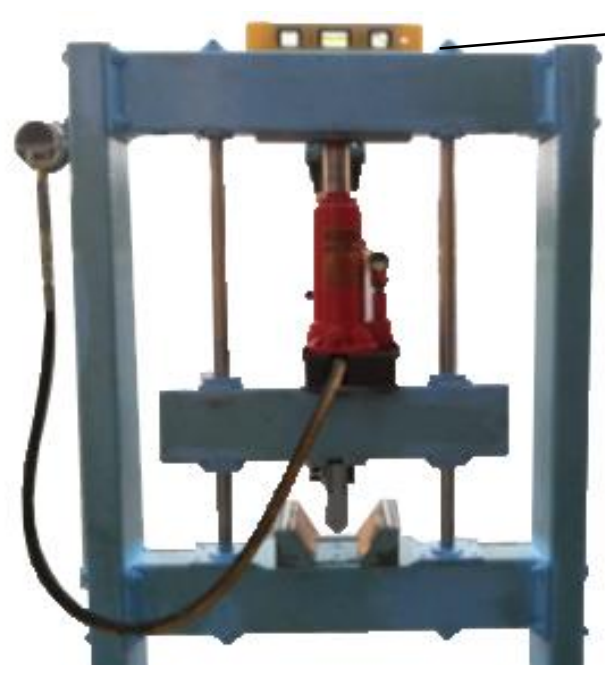

Waterpass

Gambar 11. Mesin tidak mengalami kemiringan setelah pengujian tarik dan tekuk

\section{Kesimpulan}

Mesin Uji Universal atau Universal Testing Machine (UTM) yang dibuat terdiri atas uji tarik (tensile test) dan uji tekuk (bending test) plat besi, dan telah diuji operasinya untuk melakukan uji tarik dan uji tekuk, dan dapat ditarik kesimpulan sebagai berikut: 
1. Kapasitas beban pada mesin UTM ini adalah $5000 \mathrm{~kg}$ untuk konstruksi, namun untuk uji tarik dan uji tekuk hanya dapat dilakukan dengan beban $1400 \mathrm{~kg}$ karena ketersediaan komponen hidrolik di pasaran.

2. Perancangan mesin UTM dengan fitur uji tarik dan uji tekuk telah memenuhi kebutuhan atau ketentuan perancangan alat disertai dengan analisis elemen hingga pada rancangan alat tersebut.

3. Analisis UTM menggunakan software Solidworks dengan menggunakan metode elemen hingga dan asumsi keadaan statis menunjukkan tegangan tarik maksimum yang terjadi adalah $114 \mathrm{Mpa}$ dan tegangan lentur maksimum 0,9 Mpa dengan nilai perpindahan maksimum sebesar $0.15 \mathrm{~mm}$, menunjukkan bahwa UTM aman digunakan untuk beban kerja yang ditentukan.

4. Tidak hanya berdasarkan hasil analisis, pengujian aktual UTM dilakukan dan hasilnya menunjukkan UTM mampu melaksanakan uji tarik dan uji tekuk dengan baik dan kokoh sesuai beban kerja yang ditentukan tanpa kecacatan atau kemiringan.

5. Untuk uji tarik, spesimen yang dipakai adalah material SS 400 dan SUS 304 dengan penampang specimen berbentuk persegi panjang (rectangular cross-section) dan mempunyai variasi tebal yang berbeda. Sedangkan untuk uji tekuk menggunakan material ASTM A36 dengan ukuran 200 x 40 x $6 \mathrm{~mm}$.

Adapun saran untuk penelitian lebih lanjut adalah sebagai berikut:

1. Pengujian tarik dengan mesin UTM hanya direkomendasikan untuk material dengan elongation $50 \%$.

2. Perlu ditambahkan alat untuk mengukur pertambahan panjang specimen saat pengujian tarik.

3. Untuk melakukan tracing data yang menunjukkan reaksi spesimen terhadap pengujian, load cell dapat dipasang untuk data beban yang lebih akurat.

4. Bending test dengan metode three-point bending dapat dilakukan dengan UTM ini dengan cara modifikasi punch dan reposisi pada die.

5. Clamp UTM dibuat hanya untuk melakukan pengujian material plate. Jika ingin melakukan pengujian dengan shape yang lain dapat dioptimalisasi dengan mengubah desain clamp yang baru agar mampu mencengkram spesimen tersebut dengan kuat dan menghindari slip.

\section{Daftar Pustaka}

[1] D.R. Askeland. The Science and Engineering of Material, Alternate Edition, PWS Engineering, Boston, USA, 1985.

[2] L.Anggraini, R. Yamamoto, K. Hagi, H. Fujiwara and K. Ameyama, "Improving Mechanical Properties of Ceramic Composites by Harmonic Microstructure Control”. Advanced Materials Research. Vol. 896 (2014) 570-573.

[3] L. Anggraini and Sugeng, "Analysis of Porosity Defects in Aluminum as Part Handle Motor Vehicle Lever Processed by High-pressure Die Casting”. IOP Conference Series: Materials Science and Engineering, Vol. 367, No. 1 (2018), 012039.

[4] A. Muchta. Prinsip Kerja Hidrolik. Available: https://www.autoexpose.org [28 Oktober 2019]

[5] American Society for Testing and Materials (ASTM). Standard Test Methods for Tension Testing of Metallic Materials. ASTM International, 2013.

[6] American Society for Testing and Materials (ASTM). Standard Test Methods for Bend Testing of Material for Ductility. ASTM International, 2015.

[7] A.G. Putra. Pengaruh Variasi Proses Peregangan Terhadap Sifat Mekanik dan Struktur Mikro Baja St. 37 Pada Proses Roll Bending, Fakultas Teknik Universitas Jenderal Achmad Yani, 2010.

[8] N.A. Sutisna and M.F.A. Akbar. "FEM Simulation of Electric Car Chassis Design with Torsional Bar Technology". Journal of Mechanical Engineering and Mechatronics, Vol. 3, No. 2 (2018) 97-117. 